\title{
YIELD AND SOME QUALITY TRAITS OF WINTER WHEAT (Triticum aestivum L.) GRAIN AS INFLUENCED BY THE APPLICATION OF DIFFERENT RATES OF NITROGEN
}

\author{
Elżbieta Harasim, Marian Wesołowski \\ Department of Herbology and Plant Cultivation Techniques, University of Life Sciences in Lublin \\ 20-950 Lublin, ul. Akademicka 13 \\ e-mail: elzbieta.harasim@up.lublin.pl
}

Received: 03.01.2013

\begin{abstract}
A field study was conducted in the period 2004-2007 at the Czesławice Experimental Farm, belonging to the University of Life Sciences in Lublin, on loess-derived grey brown podzolic soil (good wheat soil complex). This study determined the effect of two levels of nitrogen fertilization on yield and the basic quality traits of grain of the winter wheat cultivar 'Muza'. The study results show the dependence of the grain quality characters mainly on variable weather conditions throughout the study period and to a lesser extent on the level of nitrogen fertilization. Good technological parameters were obtained in the seasons with low rainfall and high air temperature. The study also demonstrated that the higher rate of nitrogen tended to have a positive effect on total protein and wet gluten content, falling number, sedimentation value, and grain test weight. In spite of the lack of significant differences, the quality of gluten was found to decrease with the increasing rate of nitrogen.
\end{abstract}

Keywords: Triticum aestivum, nitrogen, grain, technological value

\section{INTRODUCTION}

Due to its use for consumption purposes, winter wheat grain must be characterized by appropriate quality traits [1]. The technological value of cereal grain is largely determined genetically, thus it is cultivar dependent. Habitat and agrotechnical conditions also have a significant modifying effect [2-4]. Among agrotechnical factors, nitrogen fertilization has the largest influence on gluten and protein content in wheat grain $[5,6]$. The proper selection of rates and the time of application of nitrogen, taking into account the plant growth stage, guarantees high effectiveness of its use. The results of many studies [7-9] prove that increased effectiveness of nitrogen, in terms of yield quantity and quality, is achieved when split doses of nitrogen are used, with the last dose delayed until the heading stage. Early doses of nitrogen stimulate the vegetative growth and affect yield quantity, whereas the later application of this nutrient has a smaller effect on yield, but may contribute to an improvement in grain quality parameters [10-12]. The results of our research confirm the effect of increased nitrogen fertilization not only on increasing wheat grain yield, but also on obtaining good grain properties [13].

The aim of the present study was to determine the effect of two levels of nitrogen fertilization on the quantity and quality of grain yield of the winter wheat cultivar 'Muza'. An assumption was made in this study that increased nitrogen fertilization would have an effect on increasing wheat grain yield, without decreasing grain quality.

\section{MATERIALS AND METHODS}

The effect of two levels of nitrogen fertilization on yield and on the basic technological quality traits of grain of the winter wheat cultivar 'Muza' was investigated in a controlled field experiment conducted in the period 2004-2007. Fertilization with nitrogen as ammonium nitrate and urea was applied at rates of 100 and $150 \mathrm{~kg}$ of nutrient per ha at two times: the 1st dose $(60$ and $95 \mathrm{~kg})$ at the beginning of plant growth - BBCH 29, whereas the 2nd dose (40 and $55 \mathrm{~kg}$ ) at the third internode stage $-\mathrm{BBCH} 33$. The experiment was carried out at the Czesławice Experimental Farm on loess-derived grey brown podzolic soil (good wheat soil complex), slightly acidic ( $\mathrm{pH}$ in $1 \mathrm{~mol} \mathrm{KCl}$ - 6.3-6.6), with a high content of phosphorus, potassium, and magnesium. The experiment was set up in 
a randomized block design in three replicates, with the plot area of $10 \mathrm{~m}^{2}$.

Vetch grown for seed was the previous crop for winter wheat. After the vetch crop was harvested, typical tillage was done, including skimming, double harrowing after skimming, and ploughing performed 3 weeks before sowing the winter crop. The time of wheat seeding was in the third 10-day period of September in all the years, and the seeding rate was 500 seeds per $\mathrm{m}^{2}$. Seeds were treated with the seed dressing Dividend 030 FS (difenoconazole $30 \mathrm{~g} \times \mathrm{l}^{-1}$ ) at a rate of $300 \mathrm{ml}$ of the fungicide per $100 \mathrm{~kg}$ of seed. Before sowing wheat, phosphorus and potassium fertilizers were applied at the following rates in $\mathrm{kg}$ per ha: $\mathrm{P}-40, \mathrm{~K}-110$.

Crop protection treatments involved chemical control of weeds and fungal diseases as well as protection against lodging. For weed control, Apyros 75 WG (sulphonylurea, at a rate of $20 \mathrm{~g} \times \mathrm{ha}^{-1}$ ) and Starane

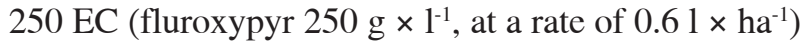
were used at full tillering stage of winter wheat $(\mathrm{BBCH}$ 29-30). Alert $375 \mathrm{SC}$ (flusilazole $125 \mathrm{~g} \times \mathrm{l}^{-1}+$ carben-

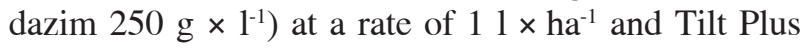

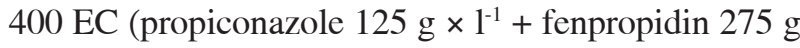
$\left.\times 1^{-1}\right)$ at a rate of $11 \times$ ha $^{-1}$ were used against fungal diseases. Lodging of wheat was prevented by applying the growth regulator Antywylegacz Płynny 675 SL (chlormequat chloride) $-2 \mathrm{l} \times$ ha $^{-1}$.

For qualitative analysis, the standards generally accepted by cereal quality laboratories were applied: grain protein content was determined by the Kjeldahl method $(\mathrm{Nx} 6,25)$ according to the ICC-Standard $105 / 2$, wet gluten content according to the standard PN-77/A-74041, the gluten index according to the standards ICC 155 and PN-93/A-74042 using a Glutomatic 2200 system, grain test weight was determined using the standard hectolitre weight apparatus according to the standard PN-73/R-74007, the falling number according to PN-ISO 3093:1996/Az1:2000, and the Zeleny sedimentation value according to the standard PN-ISO 5529:1998. The means were compared using Tukey's test at $\mathrm{p}=0.05$.

The basic meteorological elements during the study period relative to long-term means are shown in Table 1 . The first season (2004/2005) was very warm and wet, in particular during the spring and summer growing period. Adverse moisture conditions prevailed during sowing and at the beginning of the autumn growing period in the second season (2005/2006). It was only in December that there was abundant rainfall $(55.7 \mathrm{~mm})$ which replenished soil water reserves. The winter during the season in question was exceptionally cold (except for December, the mean temperature was lower than the long-term mean by $4.7^{\circ} \mathrm{C}$ in January and by $1.9{ }^{\circ} \mathrm{C}$ in February). The last year of the study $(2006 / 2007)$ was characterized by the lowest precipitation. During the growing season, it was lower by $54.8 \mathrm{~mm}$ compared to the long-term mean. But the average temperature during the entire growing season was higher by $2.4{ }^{\circ} \mathrm{C}$ compared to the long-term average.

Table 1

Weather conditions during the growing season of winter wheat

\begin{tabular}{|c|c|c|c|c|c|c|c|c|}
\hline \multirow{3}{*}{ Month } & \multicolumn{6}{|c|}{ Years } & \multirow{2}{*}{\multicolumn{2}{|c|}{$\begin{array}{l}\text { Long-term mean - } \\
\quad(1951-2005)\end{array}$}} \\
\hline & \multicolumn{2}{|c|}{$2004 / 2005$} & \multicolumn{2}{|c|}{$2005 / 2006$} & \multicolumn{2}{|c|}{$2006 / 2007$} & & \\
\hline & $\mathrm{mm}$ & ${ }^{\circ} \mathrm{C}$ & $\mathrm{mm}$ & ${ }^{\circ} \mathrm{C}$ & $\mathrm{mm}$ & ${ }^{\circ} \mathrm{C}$ & $\mathrm{mm}$ & ${ }^{\circ} \mathrm{C}$ \\
\hline IX & 21.1 & 12.5 & 23.1 & 14.7 & 10.1 & 15.1 & 51.6 & 12.6 \\
\hline$X$ & 26.1 & 9.8 & 4.2 & 8.7 & 31.0 & 9.8 & 40.1 & 7.8 \\
\hline XI & 65.5 & 2.8 & 24.6 & 2.7 & 43.7 & 4.7 & 38.1 & 2.5 \\
\hline XII & 15.8 & 1.1 & 55.7 & -1.3 & 22.7 & 2.5 & 31.5 & -1.4 \\
\hline I & 34.8 & -0.7 & 16.1 & -8.2 & 83.7 & 2.0 & 22.7 & -3.5 \\
\hline II & 35.4 & -4.0 & 24.4 & -4.6 & 23.8 & -2.0 & 25.6 & -2.7 \\
\hline III & 42.2 & -1.1 & 47.4 & -2.0 & 32.6 & 5.7 & 26.3 & 1.1 \\
\hline IV & 21.2 & 8.4 & 26.1 & 8.5 & 16.4 & 8.2 & 40.2 & 7.4 \\
\hline $\mathrm{V}$ & 146.9 & 13.0 & 68.1 & 13.3 & 46.4 & 14.9 & 57.7 & 13.0 \\
\hline VI & 48.0 & 15.6 & 23.2 & 16.9 & 85.1 & 18.2 & 65.7 & 16.2 \\
\hline VII & 55.8 & 19.8 & 26.6 & 21.1 & 70.0 & 18.8 & 83.5 & 17.8 \\
\hline VIII & 46.2 & 17.0 & 202.5 & 17.4 & 31.4 & 18.8 & 68.6 & 17.1 \\
\hline Total & 559.0 & & 542.0 & & 496.9 & & 551.7 & \\
\hline Mean & & 7.8 & & 7.3 & & 9.7 & & 7.3 \\
\hline
\end{tabular}




\section{RESULTS}

Winter wheat grain yield was significantly dependent on climatic conditions during the study period and on nitrogen fertilization. It was the highest $(9.59 \mathrm{t} \times$ $\mathrm{ha}^{-1}$ ) in the first year of the experiment; in the other two years, grain yield was much lower -6.94 in the third year of the study and $7.26 \mathrm{t} \times \mathrm{ha}^{-1}$ in the second year. The difference in grain yield between years was more than $27 \%$. Nitrogen fertilization at the rate of $150 \mathrm{~kg} \times$ $\mathrm{ha}^{-1}$ significantly increased winter wheat productivity by $3.7 \%$ relative to the rate of $100 \mathrm{~kg} \times$ ha $^{-1}$ (Table 2).

The total protein content varied between years. Significantly more protein was found in grain harvested in $2006(14.4 \%)$ than in the seasons of $2005(10.8 \%)$ and $2007(11.8 \%)$. The situation was similar in the case of wet gluten content (Table 3). The highest amount of this component was found in wheat grain harvested in the second year of the study (2006) - 34.6\%. In the other years of the experiment, the percentage of gluten was found to be $25.9-32.2 \%$. An increase in the rate of nitrogen from 100 to $150 \mathrm{~kg} \times \mathrm{ha}^{-1}$ resulted in a positive trend towards an increase in protein and gluten content in two years of the three-year study.

The quality of gluten depended only on year. The highest values of the gluten index were obtained in the first year of the experiment - 96. In the next years, gluten quality proved to be low (84) and very low (61).

Grain test weight was also significantly correlated with years (Table 3 ). This character was found to have the highest value in $2007-78.3 \mathrm{~kg} \times \mathrm{hl}^{-1}$, whereas in the years 2005-2006 it was lower by $1.6-6.0 \%$. A beneficial, though statistically not proven, effect of the higher rate of nitrogen $\left(150 \mathrm{~kg} \times \mathrm{ha}^{-1}\right)$ on grain size and shape was found in the first and third years of the study.

Table 2

Winter wheat grain yield depending on rate of nitrogen $\left(\mathrm{t} \times \mathrm{ha}^{-1}\right)$ and years of study

\begin{tabular}{ccccc}
\hline \multirow{2}{*}{$\begin{array}{c}\text { Rate of nitrogen } \\
\left(\mathrm{kg} \times \mathrm{ha}^{-1}\right)\end{array}$} & 2005 & 2006 & 2007 & Mean \\
\cline { 2 - 5 } 100 & 9.57 & 7.15 & 6.64 & 7.78 \\
150 & 9.60 & 7.38 & 7.24 & 8.07 \\
Mean & 9.59 & 7.26 & 6.94 & 7.93 \\
\hline \multirow{2}{*}{$\operatorname{LSD}_{(0.05)}$ between } & \multicolumn{4}{c}{ years -0.152} \\
\hline
\end{tabular}

Table 3

Quality traits of winter wheat grain depending on rate of nitrogen and year

\begin{tabular}{|c|c|c|c|c|c|c|c|c|}
\hline \multirow{3}{*}{$\begin{array}{l}\text { Rate of nitrogen } \\
\qquad\left(\mathrm{kg} \times \mathrm{ha}^{-1}\right)\end{array}$} & \multicolumn{8}{|c|}{ Year } \\
\hline & 2005 & 2006 & 2007 & Mean & 2005 & 2006 & 2007 & Mean \\
\hline & \multicolumn{4}{|c|}{ Protein content $(\%)$} & \multicolumn{4}{|c|}{ Gluten content $(\%)$} \\
\hline 100 & 10.5 & 14.4 & 11.3 & 12.1 & 25.2 & 35.2 & 30.4 & 30.2 \\
\hline 150 & 11.0 & 14.4 & 12.3 & 12.5 & 26.6 & 34.1 & 34.1 & 31.6 \\
\hline Mean & 10.8 & 14.4 & 11.8 & 12.3 & 25.9 & 34.6 & 32.2 & 30.9 \\
\hline \multirow{3}{*}{$\operatorname{LSD}_{(0.05)}$ between: } & & years; & 2.08 & & & years; & 9.9 & \\
\hline & & rates of & en; NS & & & rates of & en; $\mathrm{N}$ & \\
\hline & \multicolumn{4}{|c|}{ Gluten index } & \multicolumn{4}{|c|}{ Grain test weight $\left(\mathrm{kg} \times \mathrm{hl}^{-1}\right)$} \\
\hline 100 & 98 & 83 & 64 & 82 & 76.7 & 73.7 & 78.2 & 76.2 \\
\hline 150 & 93 & 85 & 57 & 78 & 77.2 & 73.4 & 78.4 & 76.3 \\
\hline Mean & 96 & 84 & 61 & 80 & 77.0 & 73.6 & 78.3 & 76.3 \\
\hline \multirow{3}{*}{$\operatorname{LSD}_{(0.05)}$ between: } & & years & 19.6 & & & years; & 1.6 & \\
\hline & \multicolumn{4}{|c|}{ rates of nitrogen; NS } & \multicolumn{4}{|c|}{ rates of nitrogen; NS } \\
\hline & \multicolumn{4}{|c|}{ Falling number (s) } & \multicolumn{4}{|c|}{ Sedimentation value $\left(\mathrm{cm}^{3}\right)$} \\
\hline 100 & 350 & 247 & 372 & 323 & 25 & 35 & 29 & 30 \\
\hline 150 & 407 & 216 & 377 & 333 & 28 & 38 & 31 & 32 \\
\hline Mean & 379 & 232 & 374 & 328 & 26 & 37 & 30 & 31 \\
\hline \multirow{2}{*}{$\operatorname{LSD}_{(0.05)}$ between: } & & years & NS & & & years; & & \\
\hline & & rates of & en; NS & & & rates of & en; 1 . & \\
\hline
\end{tabular}

$\mathrm{NS}$ - not significant 
The activity of amylolytic enzymes, which determine the degree of starch degradation, expressed by the falling number was primarily modified by agro-meteorological conditions during the study period. Very high values of this trait were obtained in the years 2005 (379) and 2007 (374). The slight variation under the influence of the rates of nitrogen was practically irrelevant.

The Zeleny sedimentation value was affected by year and fertilizer factor. The highest value of the trait in question was found in the second year of the study $\left(37 \mathrm{~cm}^{3}\right)$. In the other years, the sedimentation value was lower by $18.9-29.7 \%$. The higher rate of nitrogen $\left(150 \mathrm{~kg} \times \mathrm{ha}^{-1}\right)$ increased the average sedimentation value by $6 \%$.

\section{DISCUSSION}

The obtained study results show a significant effect of environmental factors and level of nitrogen fertilization on winter wheat grain yield. Precipitation and air temperature, as elements of agroclimate, belong to natural yield-forming factors that are characterized by large variation. The effects of these both parameters on yield quantity and quality are very strong and still relatively uncontrolled $[14,15]$. In the present study, in the years with adverse weather conditions (2006-2007), characterized by rainfall deficit, the grain yield was $24.3-27.6 \%$ lower than in the year in which the weather conditions were conducive to higher yields (2005). These results are in agreement with the results of the research of Koźmińs ki and M i chals ka [16] who demonstrated that the proper process of plant growth and the yielding ability of plants were dependent not only on the optimal factors but also on the extreme ones which may have an effect on reducing yield.

The results of many experiments $[2,17-21]$ reveal the influence of different levels of nitrogen fertilization on the quantity of spring and winter wheat grain yield. The present experiment also found a statistically proven positive effect of the higher rate of nitrogen $\left(150 \mathrm{~kg} \times \mathrm{ha}^{-1}\right)$ on winter wheat grain productivity. The best yield-increasing effect (a 3-9\% increase in yield) was found in a rather warm year (2006) and a very warm year (2007) with lower than average rainfall.

The technological parameters of grain varied between years and this is also evidence of the influence of weather and habitat conditions on grain quality. The content of protein and wet gluten was determined by the weather conditions during the period from heading to full grain maturity. In the dry year of 2006, both investigated parameters reached on average the highest values. In a warm season with a large amount of rainfall (2005) as well as in a very warm and dry season (2007), the values of the characters in question were found to decline: protein by $2.6-3.6$ percentage points and gluten by $2.4-8.7$ percentage points. This is consistent with the literature data [3,22] showing that sunny weather with moderate rainfall and high air temperature is the best for the production of a large amount of protein and gluten. Rainy weather, in particular during the grain ripening period, promotes increased activity of amylolytic enzymes, thus contributing to grain sprouting. In 2005 in the period before grain harvest, there was higher rainfall and lower air temperature compared to the previous years. In the above-mentioned year, these conditions caused an increase in the falling number and higher differences in its values than in the other warmer years.

Among all agricultural treatments, nitrogen fertilization is not only a yield-increasing factor that has the strongest effect, but it is also a factor that causes the greatest changes in the chemical composition of grain $[20,23]$. In the present study, in spite of the lack of significant differences, an increase in the rate of nitrogen to $150 \mathrm{~kg} \times$ ha $^{-1}$ resulted in positive changes in the amount of protein and wet gluten in winter wheat grain. But the values of the gluten index, which determine grain quality, decreased. Similar correlations were found by Achremowicz et al. [24] as well as by B orkow ska et al. [25]. A negative effect of increasing nitrogen fertilization on gluten quality was found in two years of the study.

The present study showed a beneficial effect of increasing nitrogen fertilization on the quality of structure-forming protein substances, as measured by the Zeleny sedimentation test. The sedimentation value significantly increased in each year of the study in the range of 7-12\%. In the studies of B u d z y ń s k i et al. [20] as well as Kościelniak and Rothkaehl [26] the results of the above-mentioned test increased linearly to the level of $180-240 \mathrm{~kg} \mathrm{~N} \times \mathrm{ha}^{-1}$. In the research of $\mathrm{P} \mathrm{od} \mathrm{ols} \mathrm{k} \mathrm{a} \mathrm{et} \mathrm{al.} \mathrm{[27],} \mathrm{such} \mathrm{an} \mathrm{increase} \mathrm{was}$ found up to the rate of $200 \mathrm{~kg} \mathrm{~N} \times \mathrm{ha}^{-1}$.

To sum up, it can be concluded that an increase in nitrogen fertilization from $100 \mathrm{~kg} \times \mathrm{ha}^{-1}$ to a rate of $150 \mathrm{~kg} \times \mathrm{ha}^{-1}$ is a yield-increasing factor that has a strong effect. Intensive nitrogen fertilization is also a factor that results in positive tendencies with regard to the chemical composition of grain. The meteorological conditions during the study period played a more important role in determining the quality of grain of the studied wheat cultivar.

\section{CONCLUSIONS}

1. A warm and sufficiently wet growing season was conducive to high winter wheat yields (more than $9 \mathrm{tha}^{-1}$ ). In the warmer years but with lower than average rainfall, wheat productivity declined. 
2. The winter wheat cultivar 'Muza' responded positively in terms of grain yield to the application of an increased rate of nitrogen fertilizer $\left(150 \mathrm{~kg} \times \mathrm{ha}^{-1}\right)$.

3. An increase in the rate of nitrogen to $150 \mathrm{~kg} \times \mathrm{ha}^{-1}$ resulted in a significant increase in the Zeleny sedimentation value. However, the study did not find a statistically proven effect of intensive nitrogen fertilization on the other grain quality parameters, but it was found to positively affect protein and wet gluten content.

\section{Acknowledgements}

Research supported by the Ministry of Science and Higher Education of Poland as part of the statutory activities of the Department of Herbology and Plant Cultivation Techniques, University of Life Sciences In Lublin.

\section{Authors' contributions}

The following declarations about authors' contributions to the research have been made: designing the experiments: $\mathrm{MW}, \mathrm{EH}$; field work: $\mathrm{EH}$; data analyses: EH, writing the manuscript: EH.

\section{REFERENCES}

1. Podolska G., Stankowski S., Dworakowski T. Wpływ dawki nawożenia azotem na wielkość plonu i wartość technologiczną ziarna wybranych odmian pszenicy ozimej. / The effect of nitrogen fertilization on yielding and technological values of winter wheat cultivars. Fragm. Agron. 2007; 2(94): 274-282. (in Polish)

2. Borkowska H., Grundas S., Styk B. Wysokość i jakość plonów niektórych odmian pszenicy jarej w zależności od nawożenia azotowego. / Yield quantity and quality in some spring wheat cultivars in relation to nitrogen fertilization. Ann. Univ. Mariae Curie Skłodowska, Sect. E, Agricultura; 2002; 57: 99-103. (in Polish)

3. Stankowski S., Smagacz J., Hury G., Ułasik S. Wpływ intensywności nawożenia azotem na jakość ziarna i mąki odmian pszenicy ozimej. / Effect of nitrogen fertilization intensity on grain and flour quality of winter wheat cultivars. Acta Sci. Pol., Agricultura; 2008; 7(3): 105-114. (in Polish)

4. Otteson, B.N., Mergoum, M., Ransom, J.K. Seeding rate and nitrogen management on milling and baking quality of hard red spring wheat genotypes. Crop Science; 2008; 48: 749-755. http://dx.doi.org/10.2135/cropsci2007. 08.0473

5. Stankowski S., Podolska G., Stypuła G. Wpływ wybranych sposobów ochrony roślin na plon i jakość ziarna odmian pszenicy ozimej. / The effect of some plant protection systems on yield and grain quality of winter wheat cultivars. Short communication. Biul. IHAR; 2001; 218/219: 155-159. (in Polish)
6. Knapowski T., Ralcewicz M. Ocena wskaźników jakościowych ziarna i mąki pszenicy ozimej w zależności od zróżnicowanego nawożenia azotem. / Estimation of the quality features of winter wheat corn and flour in the relation to diversificated nitrogen fertilization. Ann. Univ. Mariae $\mathrm{Cu}-$ rie-Sklodowska, Sect. E, 2004; 59(2): 959-968. (in Polish)

7. Fowler D.B. Crop nitrogen demand and grain protein concentration of spring and winter wheat. Agron. J. 2003; 95 : 260-265. http://dx.doi.org/10.2134/agronj2003. 0260

8. Lopez-Bellido L., Lopez-Bellido R.J., Lopez-Bellido F.J. Fertilizer nitrogen efficiency in $d u$ rum wheat under rainfed Mediterranean conditions: Effect of split application. Agron. J. 2006;98:55-62. http://dx.doi. org/10.2134/agronj2005.0017

9. Gao X., Lukow O.M., Grant C.A. Grain concentrations of protein, iron and zinc and bread making quality in spring wheat as affected by seeding date and nitrogen fertilizer management. J. Geochemical Exploration; 2012; 121: 36-44. http://dx.doi.org/ 10.1016/j.gexplo.2012.02.005

10. Guttieri M.J., McLean R., Stark J.C., Sou$\mathrm{za}$ E. Managing irrigation and nitrogen fertility of hard spring wheats for optimum bread and noodle quality. Crop Sci. 2005; 45: 2049-2059. http://dx.doi.org/10.2135/cropsci 2004.0756

11. Budzyński W., Bielski S. Wpływ nawożenia azotem na plonowanie pszenicy ozimej. / Influence of nitrogen fertilization on technological quality of winter wheat grain. Fragm. Agron. 2008; 1(97): 27-38. (in Polish)

12. Podolsk a G. Wpływ dawki i sposobu nawożenia azotem na plon i wartość technologiczną ziarna odmian pszenicy ozimej. / Effect of nitrogen fertilization doses and way of its application on yield and technological quality of winter wheat cultivars grain. Acta Sci. Pol., Agricultura; 2008; 7(1): 57-65. (in Polish)

13. Harasim E., Wesołowska-Trojanowska M. Wpływ nawożenia azotem na plonowanie i jakość technologiczną ziarna pszenicy ozimej. / Influence of nitrogen fertilization on yielding and quality of winter wheat grain. Pam. Puł. 2010; 152: 77-84. (in Polish)

14. Rudnicki F., Wasilewski P. Wpływ doboru gatunków i ilości opadów na wydajność jarych mieszanek zbożowych. /Influence of species choice and rainfall sum on field of cereals spring mixture. Fragm. Agronom. 1993; 4(40): 95-96. (in Polish)

15. Flagella Z., Giuliani M.M., Giuzio L., Volpi Ch., Masci S. Influence of water deficit on durum wheat storage protein composition and technological quality. Europ. J. Agronomy; 2010; 33: 197-210. http://dx.doi.org/ 10.1016/j.eja.2010.05.006

16. Koźmiński C., Michalska B. Określanie temperatury gleby pod jęczmieniem jarym na podstawie standardowych danych meteorologicznych. / Determination of soil temperature under spring barley on the basis of standard meteorological factors. Rocz. Gleb. 1991; 42,1/2: 5-16. (in Polish)

17. Achremowicz B., Borkowska H., Styk B. Wpływ poziomów nawożenia azotowego na plonowanie niektórych odmian pszenicy jarej. / The effect of two levels 
of nitrogen fertilization on the yielding of certain varieties of spring wheat. Ann. Univ. Mariae Curie-Sklodowska, Sect. E, 1994; 49: 9-64. (in Polish)

18. R a ch oń L. Studia nad plonowaniem i jakością pszenicy twardej (Triticum durum Desf.). / Studies on the yielding and quality of hard wheat (Triticum durum Desf.). Rozprawy Naukowe. Wyd. AR w Lublinie, 2001; 248. (in Polish)

19. Fotyma M. Fertilizer consumption by crop. Naw. Nawoż. (Fert. Fertil.); 2003; 1: 30-43.

20. Budzyński W., Borysewicz J., Bielski S. Wpływ poziomu nawożenia azotem na plonowanie i jakość technologiczną ziarna pszenicy ozimej. / The effects of nitrogen level on yield and technological parameters of winter wheat grain. Pam. Puł. 2004; 135: 33-44. (in Polish)

21. Buczek J,. Bobrecka-Jamro D., Jarecki W. Plon i jakość ziarna wybranych odmian pszenicy jarej w zależności od dawki i terminu stosowania azotu. / Yield and quality of grain of selected spring wheat cultivars depending on the dose and the time of nitrogen application. Fragm. Agron. 2011; 28(4): 7-15. (in Polish)

22. Goodling M.J., Smith G.P. The potential to use climate, variety and nitrogen relationships to optimise wheat quality. Short Communications Fifth Congress ESA. 1998; 1: 229-230.

23. Cacak-Pietrzak G., Ceglińska A., Sułek A. Wpływ nawożenia azotem i antywylegaczy na plon i jakość ziarna pszenicy ozimej. / Effect of nitrogen fertilization and retardants on yield and quality of winter wheat grain. Pam. Pul. 2005; 140: 25-33. (in Polish)

24. Achremowicz B., Borkowska H., Styk B., Grundas S. Wpływ nawożenia azotowego na jakość glutenu pszenicy jarej. / The effect of nitrogen fertilization on gluten quality in spring wheat grain. Biul. IHAR, 1995; 193: 29-34. (in Polish)

25. Borkowska H., Grundas S., Styk B. Plonowanie kilku odmian pszenicy jarej w zależności od poziomu nawożenia azotowego. / The yielding of a few spring wheat cultivars depending on the level of nitrogen fertilization.
Ann. Univ. Mariae Curie-Sklodowska, Sect. E, 1999; 54: 21-29.

26. Kościelniak W., Rothkaehl J. Wpływ nawożenia azotem na plonowanie i wartość technologiczną ziarna jakościowych odmian pszenicy ozimej. / Effect of nitrogen fertilization on yield and technological value of grain quality of winter wheat cultivars. Prz. Zboż.-Młyn. 2000; 7: 7-11. (in Polish)

27. Podolska G., Krasowicz S., Sułek A. Ocena ekonomiczna i jakościowa uprawy pszenicy ozimej przy róznym poziomie nawożenia azotem. / Economic and quality evaluation of winter wheat cultivation in relation to different nitrogen fertilization levels. Pam. Puł. 2005; 139: 175-188. (in Polish)

\section{Plon i wybrane cechy jakościowe ziarna pszenicy ozimej (Triticum aestivum L.) w warunkach stosowania zróżnicowanych dawek azotu}

\section{Streszczenie}

W pracy określono wpływ dwóch poziomów nawożenia azotem na plon i podstawowe cechy jakościowe ziarna pszenicy ozimej odmiany 'Muza'. Wyniki badań wskazują na zależność wyróżników jakości od zmiennych warunków pogodowych lat badań oraz od poziomu nawożenia azotem.

Korzystne parametry technologiczne uzyskano w sezonach z małą ilością opadów oraz wysoką temperaturą powietrza. Wykazano pozytywną tendencję wyższej dawki azotu na zawartość białka ogólnego i glutenu mokrego oraz wartości liczby opadania, wskaźnika sedymentacyjnego i gęstości ziarna w stanie zsypnym. Pomimo braku istotności różnic stwierdzono obniżenie jakości glutenu wraz ze wzrostem dawki azotu.

Handling Editor: Elżbieta Weryszko-Chmielewska

This is an Open Access digital version of the article distributed under the terms of the Creative Commons Attribution 3.0 License (creativecommons.org/licenses/by/3.0/), which permits redistribution, commercial and non-commercial, provided that the article is properly cited.

(C)The Author(s) 2013 Published by Polish Botanical Society 